\title{
Platelet factor 4 limits Th17 differentiation and cardiac allograft rejection
}

\author{
Guanfang Shi, ${ }^{1}$ David J. Field, ${ }^{1}$ Kyung-ae Ko, ${ }^{1}$ Sara Ture, ${ }^{1}$ Kalyan Srivastava, ${ }^{1}$ Scott Levy, ${ }^{1}$ \\ M. Anna Kowalska, ${ }^{2}$ Mortimer Poncz, ${ }^{2,3}$ Deborah J. Fowell, ${ }^{4}$ and Craig N. Morrell ${ }^{1}$
}

\begin{abstract}
${ }^{1}$ Aab Cardiovascular Research Institute, University of Rochester School of Medicine and Dentistry, Rochester, New York, USA. 2Division of Pediatric Hematology at the Children's Hospital of Philadelphia, Philadelphia, Pennsylvania, USA. ${ }^{3}$ Department of Pediatrics, The Perelman School of Medicine, University of Pennsylvania, Philadelphia, Pennsylvania, USA. ${ }^{4}$ Department of Microbiology and Immunology, Center for Vaccine Biology and Immunology, University of Rochester School of Medicine and Dentistry, Rochester, New York, USA.
\end{abstract}

\begin{abstract}
Th cells are the major effector cells in transplant rejection and can be divided into Th1, Th2, Th17, and Treg subsets. Th differentiation is controlled by transcription factor expression, which is driven by positive and negative cytokine and chemokine stimuli at the time of $T$ cell activation. Here we discovered that chemokine platelet factor 4 (PF4) is a negative regulator of Th17 differentiation. PF4-deficient and platelet-deficient mice had exaggerated immune responses to cardiac transplantation, including increased numbers of infiltrating Th17 cells and increased plasma IL-17. Although PF4 has been described as a platelet-specific molecule, we found that activated $T$ cells also express PF4. Furthermore, bone marrow transplantation experiments revealed that $T$ cell-derived PF4 contributes to a restriction in Th17 differentiation. Taken together, the results of this study demonstrate that PF4 is a key regulator of Th cell development that is necessary to limit Th17 differentiation. These data likely will impact our understanding of platelet-dependent regulation of $\mathrm{T}$ cell development, which is important in many diseases, in addition to transplantation.
\end{abstract}

\section{Introduction}

Platelets are the cellular mediator of thrombosis, but it is becoming increasingly evident that platelets actively participate in inflammation and immune responses (1-5). Platelets either initiate or accelerate the immune response in diverse inflammatory diseases, including atherosclerosis, arthritis, cerebral malaria, and transplant rejection (1, 4, 6-9). Humans have about 200,000 platelets/ $\mu 1$, making platelets the most numerous circulating cell with an immune function. Platelet-derived inflammatory mediators, such as adhesion molecules, secreted small molecules, chemokines, and cytokines, all recruit and activate leukocytes both at the site of platelet deposition and systemically (3, 10-13). Major platelet-derived chemokines and cytokines include PF4/CXCL4, pro-platelet basic protein (ppbp), RANTES, and IL-1 $\beta$, among a large number of inflammatory molecules (14).

Animal models and human studies have indicated a proinflammatory role for platelets in acute transplant rejection $(15,16)$. Early descriptions from human transplant recipients demonstrated that platelets accumulate in failing renal transplants (17-19). In mouse models, platelets recruit leukocytes and facilitate their trafficking, leading to an acceleration of graft rejection $(7,20,21)$. Platelets also may promote transplant rejection through mechanisms distant from the transplant itself. Platelet-derived CD154 (CD40L) serves as a costimulatory molecule remote from the transplant inducing cardiac rejection (20). Our current studies demonstrate that platelet functions extend to regulating Th cell differentiation and responses to transplantation, adding a what we believe to be major new immunologic role for platelets.

Chemokine and cytokine signaling are important mediators of both acute graft rejection and transplant vasculopathy (22-24),

Authorship note: Guanfang Shi and David J. Field contributed equally to this work. Conflict of interest: The authors have declared that no conflict of interest exists. Citation for this article: J Clin Invest. 2014;124(2):543-552. doi:10.1172/JCI71858. but there has been little investigation into the role of plateletderived chemokines and cytokines in the development, activation, and recruitment of $\mathrm{T}$ cells. Chemokines have functions beyond directing leukocyte trafficking, such as triggering $\mathrm{T}$ cell activation, proliferation, and adhesion, as well as shaping Th cell differentiation (25-27). PF4 was the first discovered CXC chemokine and is found in platelet $\alpha$-granules at very high concentrations (28, 29). PF4 is well described as having a pathologic role in heparininduced thrombocytopenia (HIT) (30-32), but the biological roles of PF4 are not as well understood (33). Regulation of angiogenesis and megakaryopoiesis and an acceleration of atherosclerosis have all been linked to PF4 (29, 33-35), as well as the activation or proliferation of leukocytes, including neutrophils, monocytes, and NK cells $(36,37)$. Our past studies have demonstrated that PF4 assists in T cell trafficking, and others have suggested an in vitro PF4 function in Tregs development $(38,39)$. We now propose a novel role for PF4 in immune development: PF4 maintains Th cell homeostasis by limiting the development and responses of the Th17 type of $\mathrm{CD}^{+}$Th cells.

$\mathrm{T}$ cells are defined broadly as either $\mathrm{CD}^{+}$or $\mathrm{CD} 4^{+} . \mathrm{CD}^{+} \mathrm{T}$ cells are divided further into the Th cell subtypes Th1, Th2, or Th17 as effectors of immune responses, and Tregs as Th cells that suppress immune responses. Innate immune cell-derived cytokines and chemokines initiate $\mathrm{CD}^{+} \mathrm{T}$ cell differentiation. The cytokine environment at the time of $\mathrm{CD}^{+} \mathrm{T}$ cell activation initiates the expression of transcription factors that direct gene expression, leading to the development of particular Th cells. For example, Th1 development is induced by the expression of the transcription factors T-bet and STAT4 in response to IL-12 and/or IFN- $\gamma$; Th17 responses are initiated by TGF- $\beta$ - and IL- 6 -mediated expression of transcription factors such as RAR-related orphan receptor gammat (ROR- $\gamma \mathrm{t}$ ) and aryl hydrocarbon receptor (AhR). Th17 cells are IL-17-secreting CD4 ${ }^{+} \mathrm{T}$ cells first associated with autoimmune diseases $(40,41)$. A main physiologic function of Th17 
A

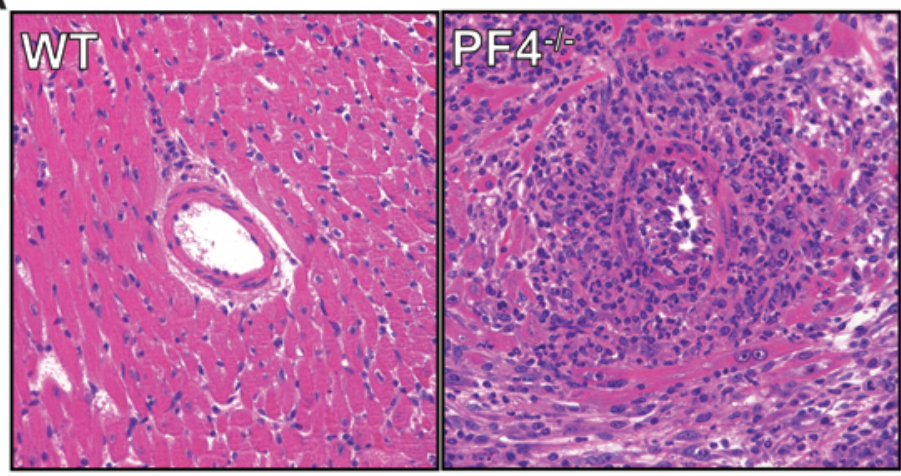

B

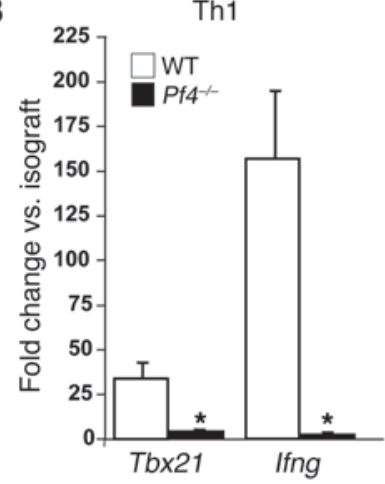

C

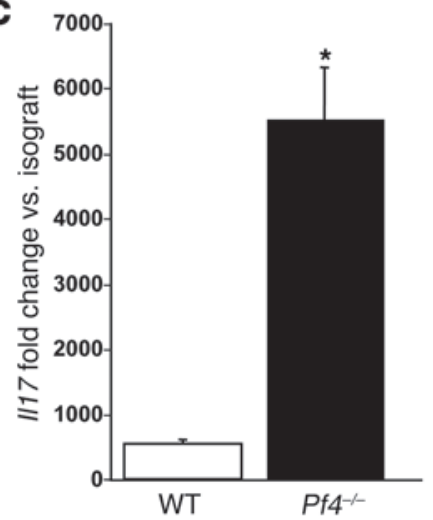

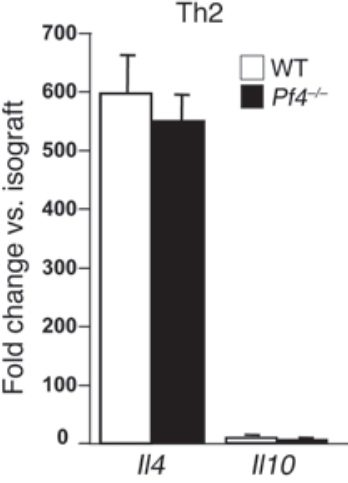

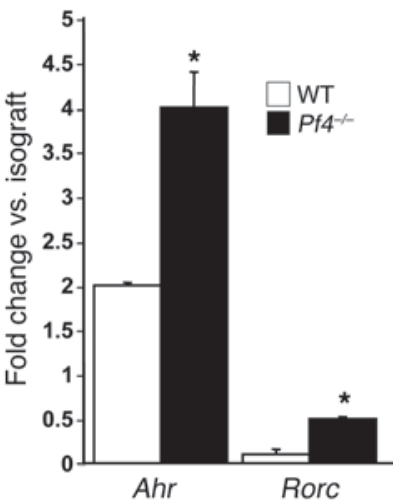

D

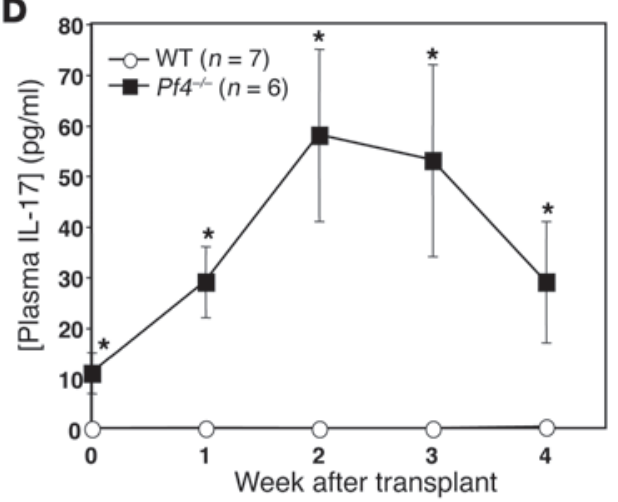

E

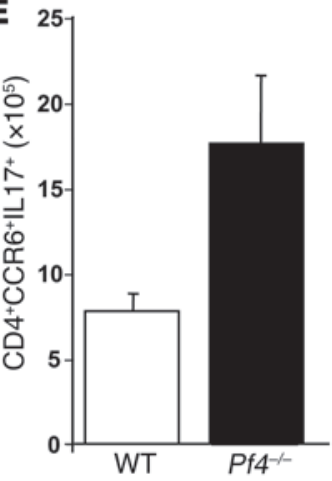

F

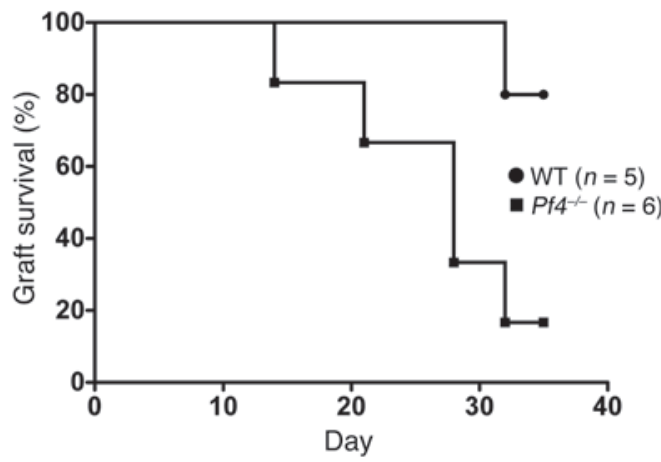

Figure 1

$P f 4^{-/-}$mice have an exaggerated Th17 response to cardiac transplantation. (A) Hearts from BM12 mice were transplanted into WT or Pf4 ${ }^{-/-}$ mice and harvested 35 days later. Pf4 ${ }^{-/}$mice had extensive inflammatory infiltrates (representative histology). (B) Heart grafts from Pf4 ${ }^{-/-}$mice had decreased expression of mRNA representative of a Th1 infiltrate, no change in Th2, and (C) increased Th17-associated mRNA ( $n=5-7$; mean \pm SD; ${ }^{*} P<0.01$ vs. isograft). (D) $P f 4^{-/-}$mice had increased plasma IL-17 and (E) increased Th17 cells in the spleen after cardiac allograft (5-7; mean \pm SD. ${ }^{*} P<0.01$ vs. WT). (F) Heart transplants in $P f 4^{-/-}$mice had shorter time to loss of transplant heartbeat. WT and $P f 4^{-/-}$were transplanted and time to rejection determined by loss of palpable transplant heartbeat $(P<0.03$, log-rank test).

cells is thought to be in antimicrobial responses to bacteria and fungi. IL-17 potently induces neutrophil activation and migration, stimulates endothelial cell activation, and leads to epithelial damage $(42,43)$. In mouse cardiac transplant models IL-17 increases early allograft inflammation, and the absence of a Th1 immune response leads to severe Th17-driven rejection responses (40, 44-46). Our prior studies in acute models of transplant rejection demonstrated that platelets increase $T$ cell recruitment and transplant rejection $(7,21)$. We have now discovered that platelets have a separate major role in more chronic transplant immune responses by regulating Th17 cell development and responses.

\section{Results}

Pf4-/- mice have an exaggerated Th17 response to cardiac transplant. Our prior studies demonstrated that PF4-induced VSMC inflammatory responses are similar to the vessel changes noted in transplant vasculopathy (47). We therefore used a chronic abdominal cardiac transplant model $(48,49)$, in which hearts from BM12 mice were 
A
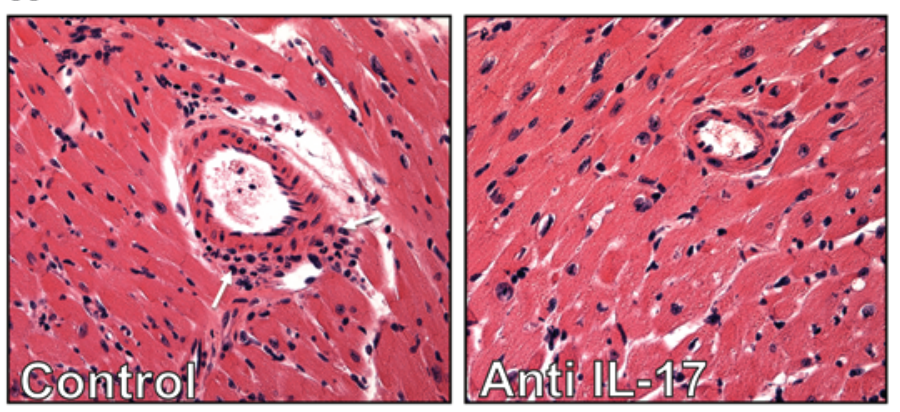

B
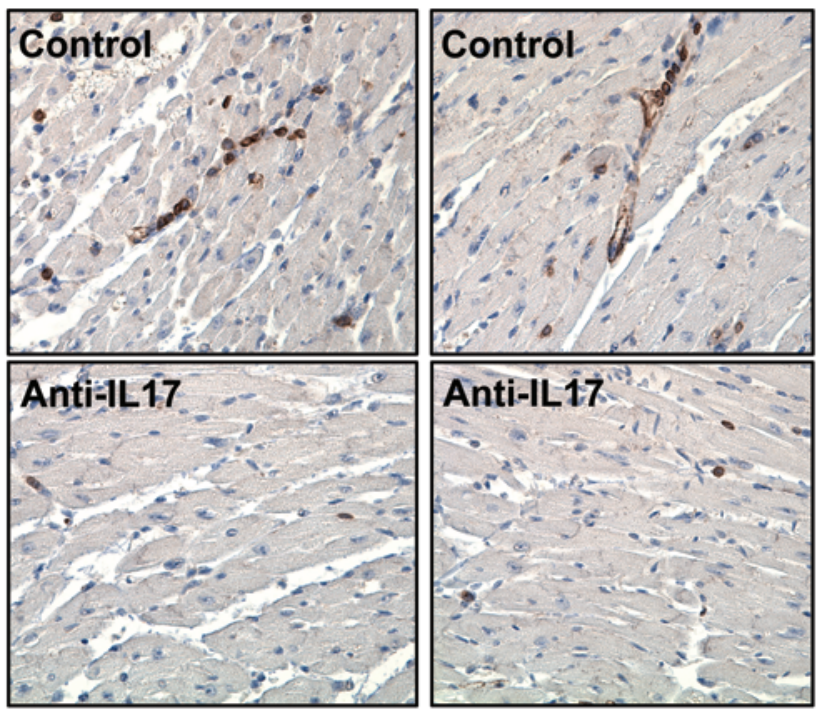

C

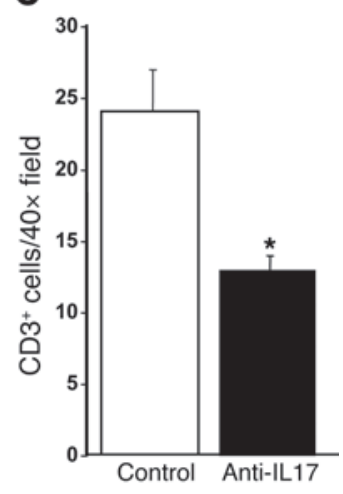

\section{Figure 2}

$\mathrm{IL}-17$ is the major mediator of graft rejection response in $\mathrm{Pf4}^{-/-}$mice. (A) IL-17 neutralizing antibody reduced inflammatory infiltrates. $\mathrm{Pf}^{-/-}$mice were given cardiac allografts and treated with control IgG or IL-17 neutralizing antibody. Original magnification, $\times 20$. Two weeks after transplant, grafts were removed, and histology was performed (arrows indicate inflammatory infiltrate), as well as (B) immunohistochemistry for $\mathrm{CD}^{+} \mathrm{T}$ cells (representative sections). (C) $\mathrm{CD}^{+}$cell quantification. $\mathrm{CD}^{+}$cells per $\times 40$ field $(n=4$; data represent mean $\pm \mathrm{SD} ;{ }^{*} P<0.01$ vs. control). transplanted into WT and $P 4^{-/-}$mice to determine the effects of PF4 on transplant vasculopathy. Thirty-five days after transplantation, heart grafts were collected and inflammatory responses characterized. As expected, WT mice had mild vascular wall thickening and occasional perivascular inflammatory cell infiltrates (Figure 1A). Unexpectedly, $P f 4^{-/-}$mice had severe perivascular inflammation with large numbers of leukocytes, including numerous neutrophils and occasional eosinophils (Figure 1A). Because chronic graft rejection is largely $\mathrm{CD}^{+}$Th cell dependent, we measured effector Th cell Th1, Th2, and Th17 heart graft infiltrates by qRT-PCR and compared with isograft control heart grafts. Compared with those in WT mice, mRNA markers of a Th1 infiltrate (Tbx21 and Ifng) were greatly decreased in $P f 4^{-/}$transplants (Figure 1B). Th2 gene expression (Il4 and Il10) was unchanged (Figure 1B). Gene markers of a Th17 infiltrate (Il17, Abr, and Rorc) were increased greatly in cardiac transplants from $\mathrm{Pf}^{-/-}$mice (Figure 1C), indicating a skewing toward a Th17 response consistent with the noted pathology. We also measured intragraft Foxp3 expression as a marker of Tregs, and similar to Th17 gene markers, $P f 4^{-/-}$mice had more Tregs in the heart graft despite the severe pathology (Supplemental Figure 1; supplemental material available online with this article; doi:10.1172/ JCI71858DS1). Plasma IL-17 also was significantly elevated in Pf4 ${ }^{-/-}$mice before transplant and increased further after transplant as compared with that in WT mice (Figure 1D). The number of Th 17 cells $\left(\mathrm{CD}^{+} \mathrm{CCR}^{+} \mathrm{IL}-17^{+}\right)$in spleens of $\mathrm{Pf}^{-{ }^{--}}$mice also was increased at the time of transplant collection (Figure 1E). A separate set of WT and $P f 4^{-/-}$mice were heart transplanted, and the time to loss of graft heartbeat was determined by abdominal palpation. Over the course of the 35 days after transplant, a significantly greater number of $\mathrm{Pf}^{-{ }^{-/}-}$mice had a loss of transplant heartbeat as compared with WT mice (Figure 1F). These data demonstrate that $\mathrm{Pf4}^{-{ }^{--}}$mice have a very robust Th17 response to cardiac transplantation. Using a mouse model of nonlethal malaria that is primarily Th1 driven (50-52), we infected WT and $P f 4^{-/-}$mice with Plasmodium yoelii XNL. Seven days after infection, spleens were isolated and Th17 cells quantified. $P f 4^{-/-}$and WT mice had a similar percentage of Th17 cells after infection (Supplemental Figure 2), as well as similar numbers of post-infection total Th17 cells $\left(6.9 \times 10^{6} \pm 2.2 \times 10^{6}\right.$ vs. $6.3 \times 10^{6} \pm 5 \times 10^{6}$, KO vs. WT). This may indicate that the exaggerated Th17 response to immune stimulation in $P f 4^{-/-}$mice may not be generic, but rather be dependent on the disease process.

Elevated IL-17 is associated with increased transplant rejection (46). To demonstrate that IL-17 is the major mediator of the exaggerated inflammatory response in $P f 4^{-{ }^{-}}$mice, $P f 4^{-/}$mice were given heart transplants and treated with control IgG or anti-IL-17 antibody every 3 days and heart grafts harvested 14 days after transplant. Anti-IL-17 antibody-treated mice had greatly reduced inflammatory cell infiltrates (Figure 2A), including fewer T cells (anti-CD3 immunohistochemistry shown in Figure 2, B and C), indicating that $P f 4^{-/-}$mice have an IL-17-dependent inflammatory response. 

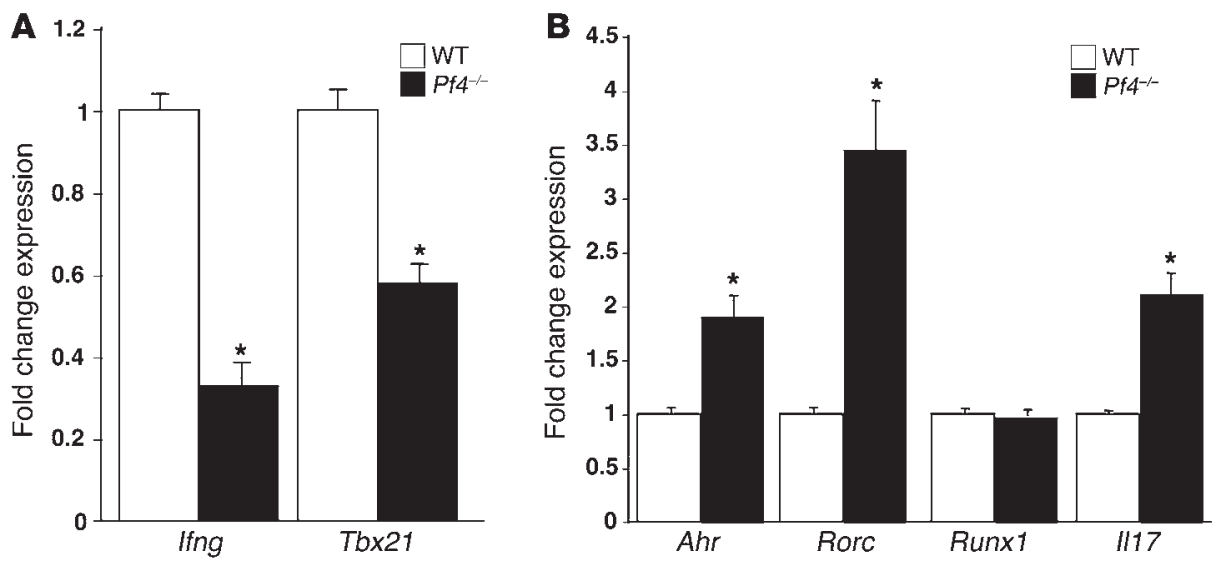

\section{Figure 3}

PF4 maintains normal Th differentiation. $\mathrm{CD}^{+} \mathrm{T}$ cells were isolated from WT and $P f 4^{-/}$mice, and qRT-PCR was performed. Pf4-/- CD4+ T cells had $(\mathbf{A})$ decreased expression of Th1, (B) increased expression of Th17, and (C) decreased expression of negative regulators of Th17 differentiation ( $n=4$; mean $\pm \mathrm{SD} ;{ }^{*} P<0.01$ vs. WT). (D) $P f 4^{-/-}$mouse inguinal lymph nodes also had increased Th17 cells $(n=4$; mean \pm SD. ${ }^{*} P<0.01$ vs. WT).
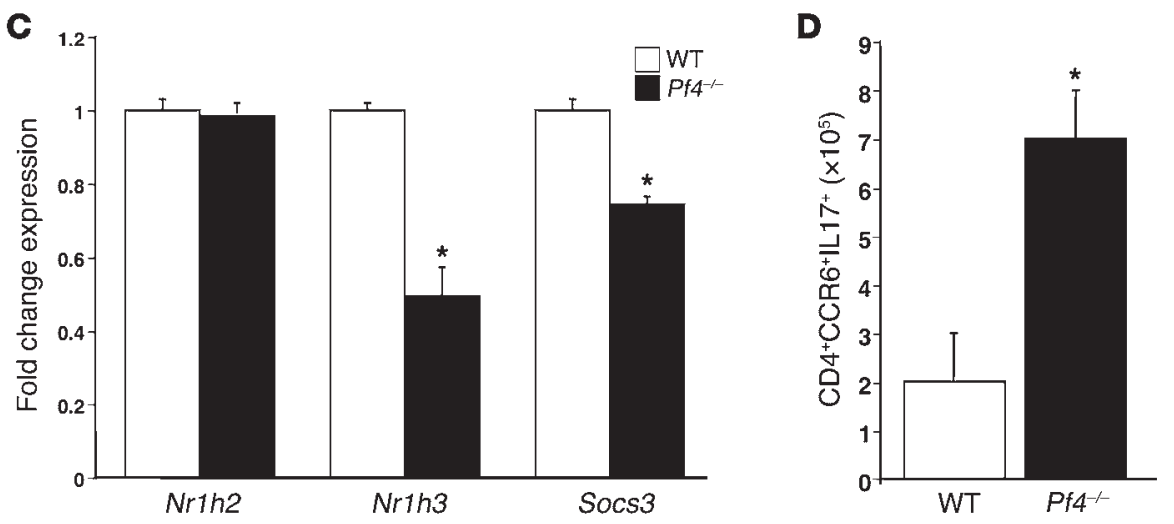

PF4 limits Th17 differentiation. Because $P f 4^{-/-}$mice had increased plasma IL-17 and increased plasma concentrations of the IL-17induced cytokine G-CSF (Supplemental Figure 3) prior to transplantation, we examined basal Th differentiation in $\mathrm{Pf}^{-/-}$mice. $\mathrm{CD}^{+} \mathrm{T}$ cells from WT and $P f 4^{-/-}$mice were isolated, and Th1 and Th17 differentiation was quantified by qRT-PCR. Expression of Th1-associated Ifng and Tbx12 was decreased (Figure 3A), and Th17-associated Il17, Abr, and Rorc expression increased in Pf4-/mice compared with WT (Figure 3B). Similarly, expression genes associated with suppression of Th17 differentiation (Nr1h3 and Socs3) was decreased in $\mathrm{Pf}^{-{ }^{-/}}$mice (Figure 3C). The number of Th17 cells $\left(\mathrm{CD}^{+} \mathrm{CCR} 6^{+} \mathrm{IL}-17^{+}\right)$also was significantly increased in ingui-

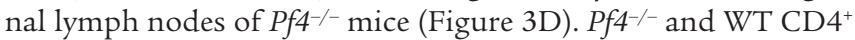
T cells had similar Foxp 3 mRNA expression (data not shown) and $\mathrm{CD}^{+} \mathrm{CD} 25^{+} \mathrm{Foxp}^{+}$cells in their spleen (Supplemental Figure 4). IL-17-positive Tregs were not noted either before or after transplant (data not shown). These data demonstrate that PF4 has an important role in Th cell development and homeostasis.

To determine whether Th17 skewing in $P 4^{-/-}$mice is a direct result of loss of PF4, plasma IL-17 was measured in $\mathrm{Pf} 4^{-/-}$and $\mathrm{Pf}^{-/-}$mice transgenic for human PF4 (Pf4-/-/hPF4-Tg mice) (33). Pf4 $4^{-/-} / \mathrm{hPF} 4-$ $\mathrm{Tg}$ mice had greatly reduced plasma IL-17 compared with $P \mathrm{ft}^{-/-}$mice (Figure 4A). To directly demonstrate that PF4 limits Th17 differentiation in vitro, naive $\mathrm{CD} 4^{+} \mathrm{T}$ cells were isolated from WT mice and differentiated under Th1- or Th17-skewing conditions in the presence of control buffer or recombinant PF4 $(1 \mu \mathrm{g} / \mathrm{ml})$. After 3 days Th1 and Th17 differentiation was determined by qRT-PCR. In Th1skewing conditions PF4 had no effect on Tbx21 expression (Figure 4B). In contrast, when $\mathrm{T}$ cells were incubated under Th17-skewing conditions, PF4 suppressed Rorc expression (Figure 4B, representative of three separate experiments, all with similar results; Supplemental Figure 5). Exogenous PF4 also reduced intracellular IL-17 and IL-17 secretion in cells differentiated in Th17-skewing conditions for 5 days (Figure 4C). To demonstrate that platelet-derived PF4 can limit Th17 differentiation, naive $\mathrm{CD}^{+} \mathrm{T}$ cells were cultured in Th0 or Th17 conditions with WT or $\mathrm{Pf}^{-{ }^{--}}$platelets (physiologic 20:1 platelet/T cell ratio). Four days later IL-17-positive T-cells were quantified. WT platelets significantly reduced Th17 differentiation as compared with no platelet and $P 4^{-/-}$platelet conditions (Figure 4D), further demonstrating that platelet PF4 directly limits Th17 differentiation. WT and $\mathrm{Pf}^{-/-}$platelets had the same effect on Th1 T cell differentiation (Supplemental Figure 6).

TGF- $\beta$ signaling induces Th17 differentiation (53). PF4 blocks TGF- $\beta$ signaling in other cell systems (54). To determine whether PF4 inhibits TGF- $\beta$ signaling in T cells, we incubated the human $\mathrm{T}$ cell line Jurkat T cells with media, TGF- $\beta$, or TGF- $\beta$ and PF4. Smad2/3 phosphorylation ( $\mathrm{p}-\mathrm{Smad} 2 / 3$ ) was determined by Western blot analysis at multiple time points, as evidence of TGF- $\beta$ signaling. PF4 greatly reduced Smad phosphorylation (Figure 4E). These studies also were performed using primary mouse naive $\mathrm{CD}^{+}$ T cells, with similar results; PF4 greatly attenuated TGF- $\beta$-induced $\mathrm{p}-\mathrm{Smad} 2 / 3$ in primary $\mathrm{T}$ cells (Figure $4 \mathrm{~F}$ ). These data indicate that PF4 may reduce Th17 differentiation, in part by blocking TGF- $\beta$.

Thrombopoietin (TPO) receptor knockout mice (Tpor ${ }^{-/} \mathrm{c}-\mathrm{mp} \mathrm{l}^{-/-}$) have very low platelet counts (55), and as a result plasma PF4 was greatly reduced in Tpor ${ }^{-1}$ mice compared with WT controls (Figure 5A). As in Pf4-/- mice, plasma IL-17 was increased in Pf4 mice, and Th17 cell numbers also increased (Figure 5A), demon- 
A

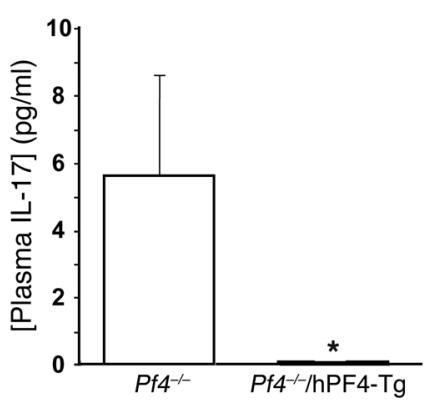

D
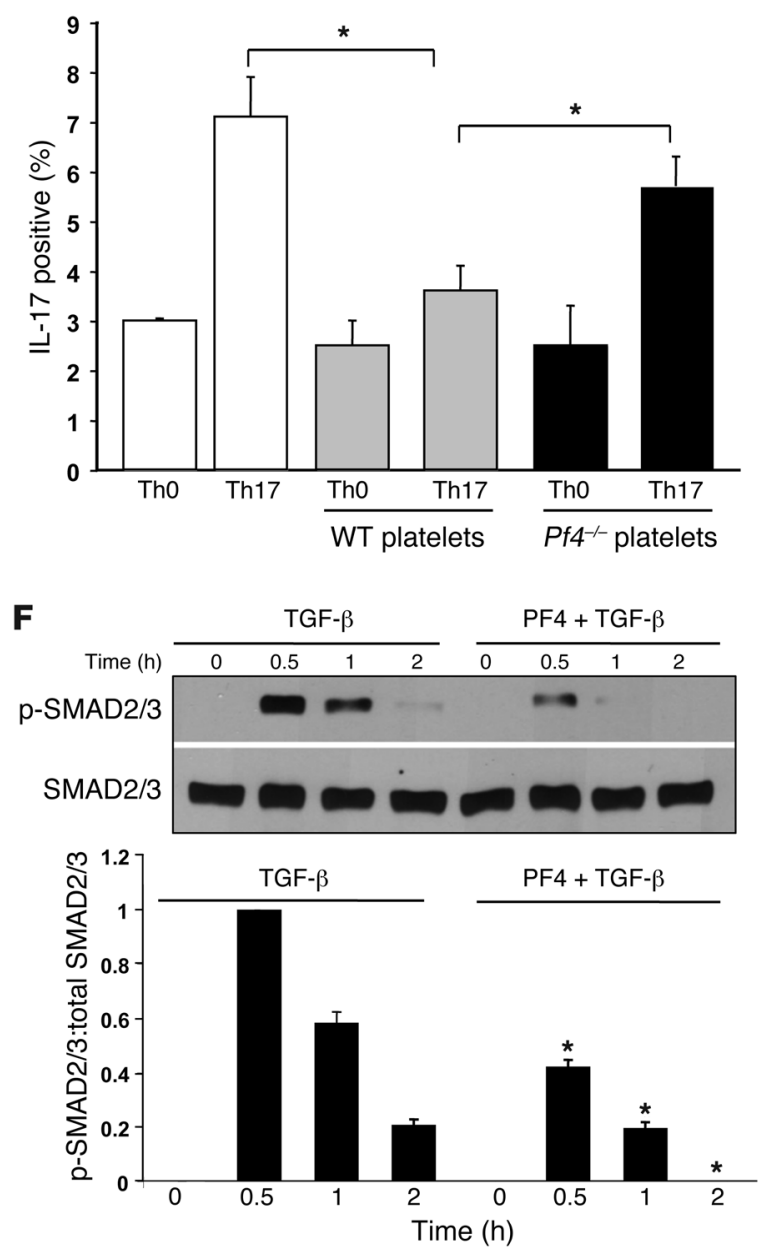

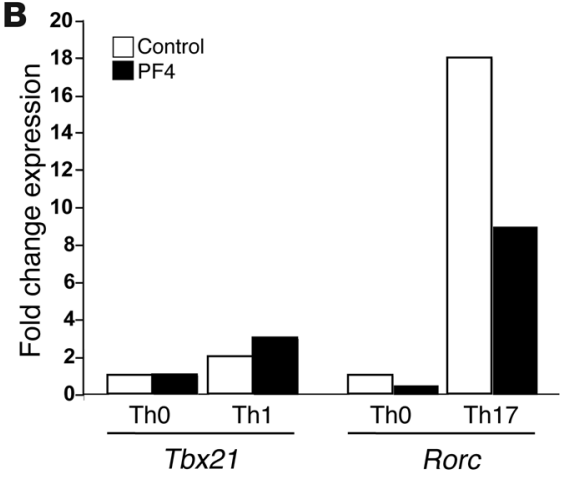

C

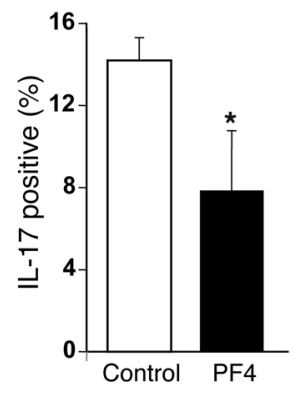

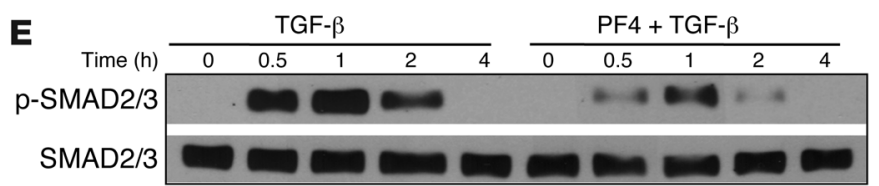

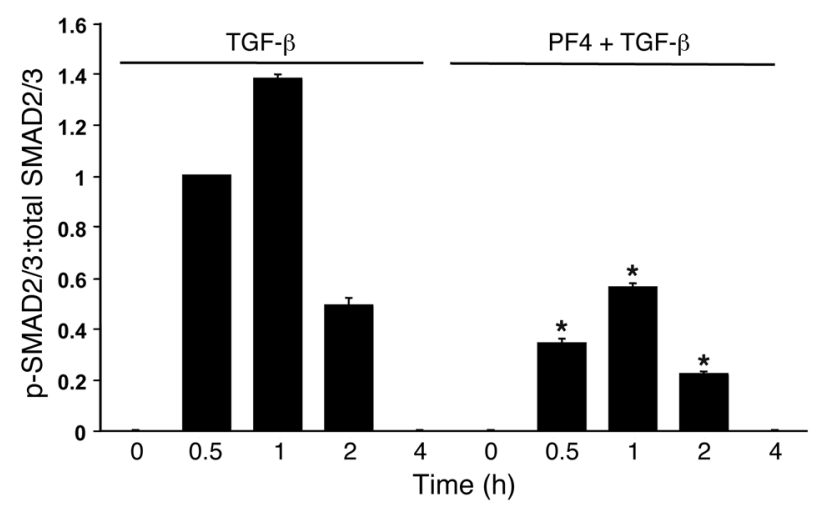

Figure 4

PF4 has a direct effect on limiting Th17 differentiation. (A) Transgenic expression of PF4 normalizes plasma IL-17 in Pf4-/- mice $(n=5-7, \pm$ SD; * $P<0.01$ vs. $P f 4^{--}$). (B) PF4 directly inhibits Th17 differentiation in vitro. $\mathrm{CD} 4^{+} \mathrm{T}$ cells were cultured in Th0, Th1, or Th17 conditions in the presence of control or PF4 $(1 \mu \mathrm{g} / \mathrm{ml})$. After 3 days representative Th1 (Tbx21) and Th17 (Rorc) gene expression was determined (representative of 3 separate experiments with the same expression pattern). (C) T cells were cultured in Th17 conditions in the presence of buffer or PF4. IL-17-positive cells (flow cytometry) and IL-17 in the supernatant (ELISA) were measured $\left(n=4\right.$; mean $\pm \mathrm{SD} .{ }^{*} P<0.03$ vs control). (D) Platelet PF4 limits Th17 differentiation. Naive CD4+ $T$ cells were incubated in Th0 or Th17 conditions with buffer, WT,or Pf4-/- platelets. IL-17-positive T cells were quantified 4 days later. WT, but not $P f 4^{-1-}$ platelets, inhibited Th17 differentiation $\left(n=4\right.$; mean \pm SD, $\left.{ }^{*} P<0.03\right)$. (E and F) PF4 blocks TGF- $\beta$-induced Smad 2/3 phosphorylation. Jurkat T cells (E) or naive mouse CD4 ${ }^{+}$T cells $(F)$ were incubated with control buffer, TGF- $\beta(2 \mathrm{ng} / \mathrm{ml})$, or TGF- $\beta$ and PF4 $(1 \mu \mathrm{g} / \mathrm{ml})$. $p$-Smad2/3 was determined by Western blot and quantified by densitometry ( $n=3$; mean $\pm \mathrm{SD},{ }^{*} P<0.01$ vs. TGF- $\beta$ only).

strating an important role for platelets in limiting steady-state Th17 differentiation. $\mathrm{CD}^{+} \mathrm{T}$ cells isolated from $P f 4$ mice also had increased expression of Th17 genes (Il17, Rorc, Abr, Figure $5 \mathrm{~B})$. When given cardiac allografts, $P f 4$ mice had pathology very similar to that of $P f 4^{-/-}$mice (Figure $5 \mathrm{C}$ ). However, unlike $\mathrm{Pf} 4^{-/-}$ mice, plasma IL-17 in Pf4 mice did not increase after transplantation (Figure 5D), indicating the potential for other relevant PF4 sources in Pf4 mice following immune stimulation.
PF4 from activated $T$ cells contributes to Th differentiation. To determine whether activated T cells are a source of PF4, we isolated total $\mathrm{T}$ cells from PF4 Cre $\mathrm{C}^{+}$EYFP-flox-stop-flox mice and incubated these cells in resting or co-stimulated culture conditions. After 24 hours both resting and stimulated $T$ cells were EYFP negative (Figure 6A). However, 48 hours after stimulation, activated CD4 ${ }^{+}$ and $\mathrm{CD}^{+} \mathrm{T}$ cells were both EYFP positive, with levels peaking after about 72 hours (Figure 6A), indicating that PF4 expression 
A

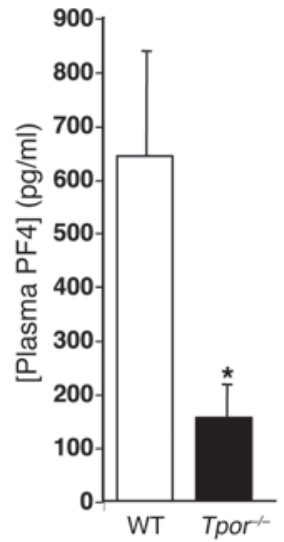

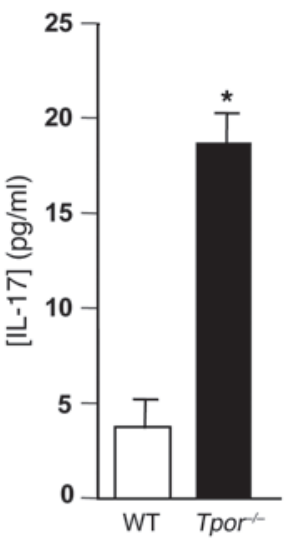

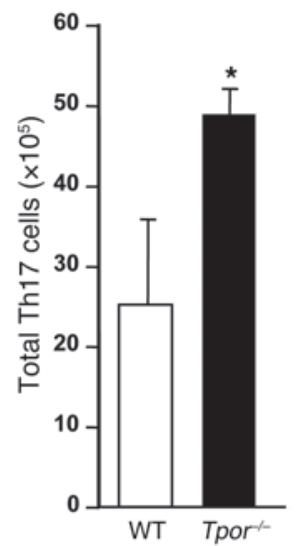

B

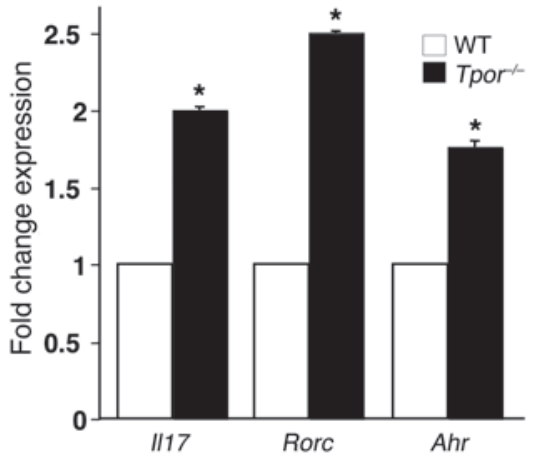

C

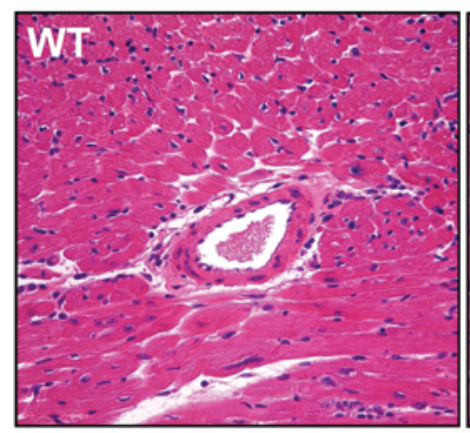

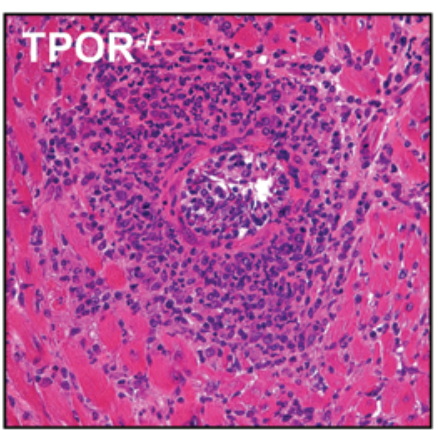

D

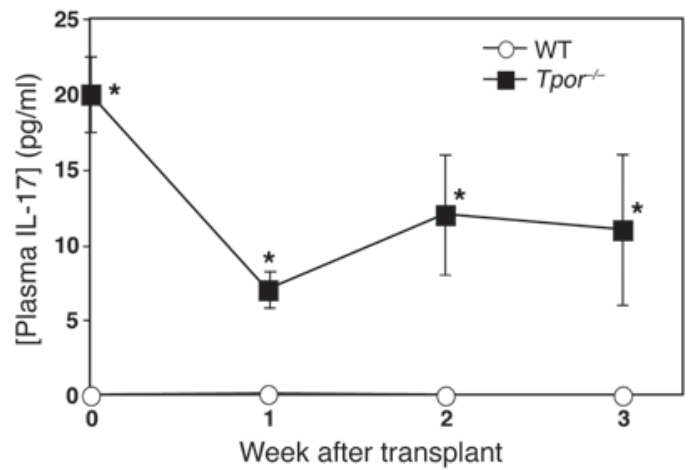

Figure 5

Platelet-deficient mice have increased Th17 differentiation. (A) Pf4 mice have greatly reduced plasma PF4, increased plasma IL-17, and increased Th17 cells $\left(n=5\right.$; mean \pm SD. ${ }^{*} P<0.01$ vs. WT). (B) Th17 gene expression is increased in CD4+ T cells from Pf4 mice $(n=4$; mean \pm SD. ${ }^{*} P<0.01$ vs. WT. (C) Inflammatory cell infiltrates after transplantation were increased in Pf4 mice compared with WT control mice (representative histology). Original magnification, $\times 20$. (D) Plasma IL-17 does not increase after transplant in Pf4 mice $\left(n=5 ;\right.$ mean \pm SEM. ${ }^{*} P<0.01$ vs. WT).

is induced in activated T cells. PF4 in the supernatant was also increased compared with resting controls 4 days after $T$ cell stimulation (Figure 6B). In addition, PMA-stimulated Jurkat $\mathrm{T}$ cells had increased CXCL4 and PF4V1 expression 24 hours after stimulation (Supplemental Figure 7). T cell PF4 expression was induced also following transplantation; Cxcl4 expression was significantly increased in $\mathrm{T}$ cells isolated from the spleens of mice 1 week after cardiac transplant (Figure 6C), further indicating that activated $\mathrm{T}$ cells produce PF4. There are reports of PF4 expression in other cells, including activated monocytes and macrophages $(56,57)$. Monocytes isolated from the spleen of WT mice did not have a post-transplant increase in Cxcl4 (Supplemental Figure 8).

To determine the relative contribution of platelet versus $T$ cell PF4 in limiting Th17 differentiation and responses in vivo, we used a nude mouse bone marrow and $\mathrm{T}$ cell reconstitution strategy to separately examine marrow sources and $T$ cell sources for PF4. Nude mice were irradiated and given WT or $\mathrm{Pf}^{-/-}$bone marrow that was $T$ cell depleted (CD90 depletion). Four weeks later mice were given WT or Pf4 $4^{-/}$T cells (Figure 6D) and cardiac transplants performed 1 week after $\mathrm{T}$ cell reconstitution. Both before and after transplant, $P f 4^{-/-} / P 4^{-/-}$(marrow/T cell) mice had significantly elevated plasma IL-17. Pf4 $4^{-/} / \mathrm{WT}$ and WT/Pf4 $4^{--}$mice showed significantly increased post-transplant plasma IL-17 levels that very closely mirrored each other (Figure 6D). To confirm that unidentified non-hematopoietic sources for PF4 do not contribute to Th17 differentiation, $\mathrm{Pf} 4^{-/-}$ mice were marrow reconstituted with WT or $P f 4^{-/-}$bone marrow and 4 weeks later heart transplanted. Pf4-/- mice with WT bone marrow had similar IL-17 levels before and after transplant (Supplemental Figure 9), indicating that non-hematopoietic PF4 is unlikely to contribute significantly to Th17 differentiation. These data suggest that platelet PF4 has a primary role in limiting Th17 differentiation under basal conditions, but with T cell responses, T cell-derived PF4 contributes to limiting Th17 differentiation.

This study demonstrates that platelets have a central role in Th homeostasis. Under basal conditions platelet-derived PF4 limits Th17 differentiation. However, activated T cells also produce PF4, and T cell PF4 may also limit Th17 differentiation after transplantation. Platelet regulation of Th cell development constitutes what we believe to be a new, and potentially very important, physiologic role for platelets that may impact many immune and inflammatory diseases beyond transplantation.

\section{Discussion}

Our studies demonstrate that platelets have a central role in maintaining Th cell homeostasis. Under steady-state conditions platelet-derived PF4 was needed to limit Th17 development. Pf4 mice had low PF4 because they had low platelet counts (the Pf4 gene itself is intact), indicating that platelet-derived PF4 has an 
A

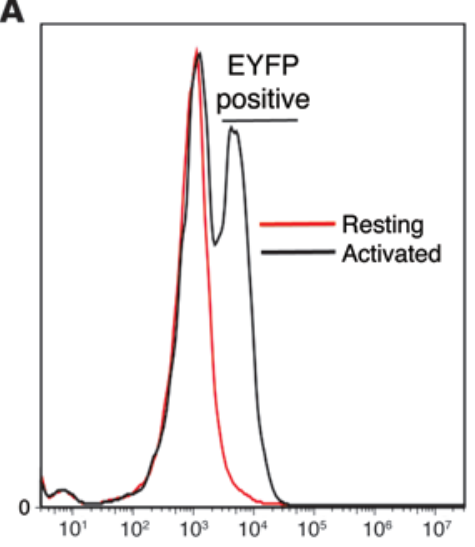

C

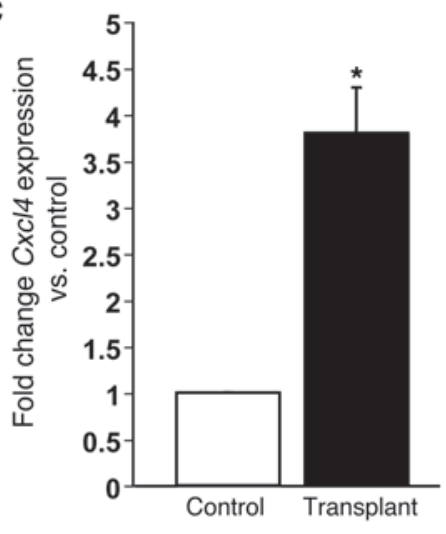

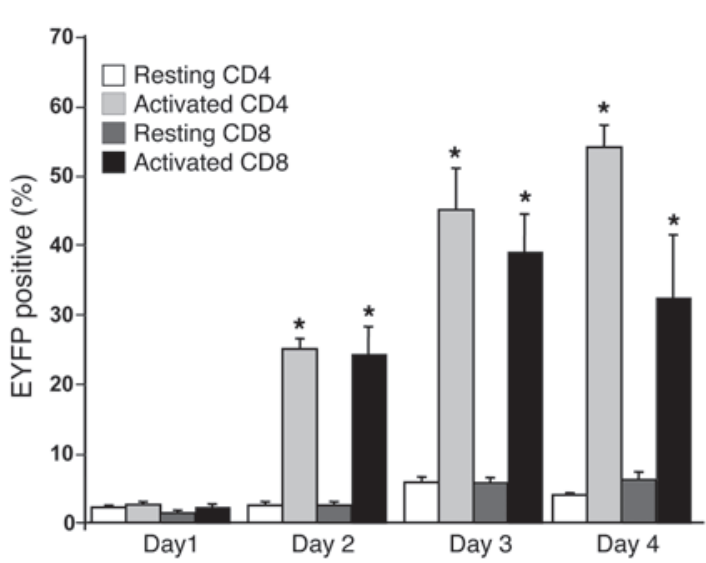

B

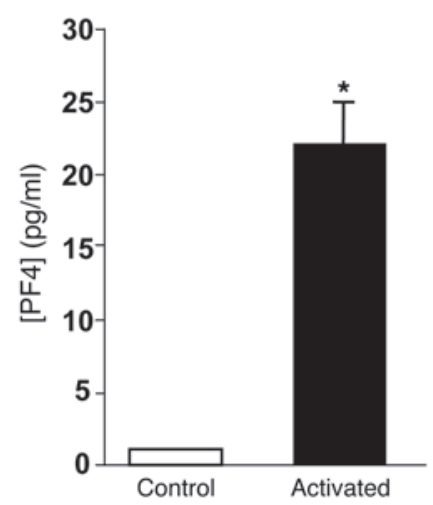

D
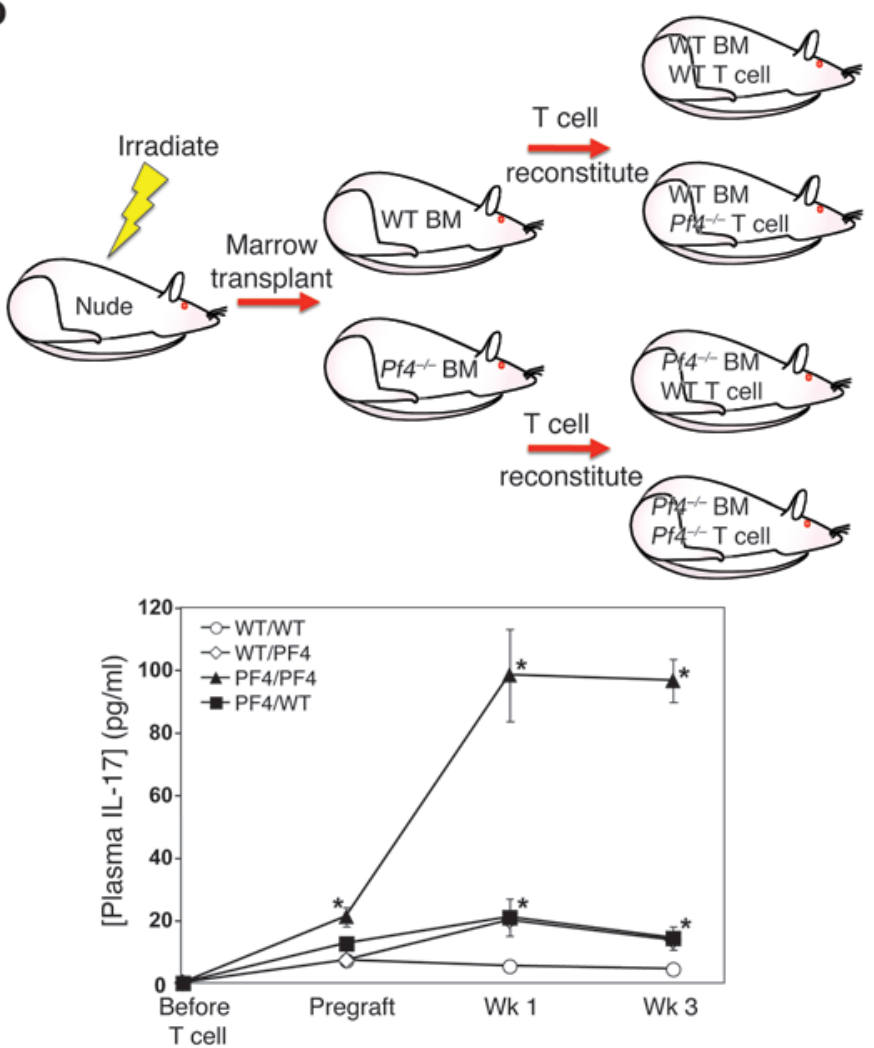

\section{Figure 6}

Activated T cell-derived PF4 limits Th17 differentiation. (A) T cells were isolated from Pf4-Cre+ Rosa26 flox-stop-flox mice and cultured in resting or activated conditions (anti-CD3 and anti-CD28, $1 \mu \mathrm{g} / \mathrm{ml}$ ). EYFP-positive CD4 ${ }^{+}$and CD8 ${ }^{+}$T cells were quantified by flow cytometry $(n=4$; mean \pm SD. ${ }^{*} P<0.01$ vs. Resting). (B) Stimulated T cells produce PF4. ELISA for PF4 in 4 day cell culture supernatants ( $n=4 ;$ mean \pm SD. ${ }^{*} P<0.01$ vs. Control). (C) PF4 expression is induced in T cells in vivo. Mice were given cardiac transplants, and after 7 days CD4+ cells were isolated to measure $C x c / 4$ expression relative to control mice by qRT-PCR $\left(n=4\right.$; mean $\pm \mathrm{SD} ;{ }^{*} P<0.01$ vs. Control). (D) T cell PF4 can compensate partially for a lack of platelet PF4. Nude mice were given WT or Pf4-/- T cell-depleted bone marrow transplants, and reconstituted with either WT or $P f 4^{-/}$T cells. Mice were then given cardiac transplants, and plasma IL-17 was measured $\left(n=4\right.$; mean \pm SD; ${ }^{*}<0.05$ vs. WT/WT).

important role in limiting basal Th17 differentiation. Activated $\mathrm{T}$ cells were also a source of post-transplant PF4 that contributed to the regulation of Th17 differentiation. Although we did not find increased PF4 in monocytes isolated from the spleen after transplant, nor a role for non-hematopoietic PF4 sources, our data do not rule out other relevant sources in other tissue beds and cell types, such as dendritic cells, after immune activation. PF4 has been associated with signaling through receptors such as CXCR3 on activated leukocytes $(58,59)$, but antibody blocking of CXCR3 had no effect on PF4 suppression of Th17 differentiation in vitro (data not shown). Instead, our data indicate that PF4 may exert its effects on Th cells in part by blocking TGF- $\beta$ signaling, an early step in Th17 differentiation. However, this may be just one regulatory mechanism for such an important process. 
These findings indicate an important role for platelets, and in particular the poorly understood chemokine PF4, in Th homeostasis. The recognition that platelets regulate Th cell development may impact many immune and inflammatory diseases beyond this transplant model. Chronic thrombocytopenia is associated with cancer, lupus, and liver disease. It is yet to be directly demonstrated that chronic thrombocytopenia leads to altered Th cell status in human disease, but it has been reported that chronically thrombocytopenic individuals have increased plasma IL-17 and that thrombocytopenia is associated with increased risk of psoriasis, a Th17-mediated auto-immune disease $(60,61)$. It may therefore be valuable to consider the role of platelets in Th responses associated with chronic thrombocytopenia. These studies, however, can be difficult to interpret because of the multiple pathways leading to the disease itself, and patients are often receiving treatment directed at $\mathrm{T}$ cells.

PF4 is most associated with the pathogenesis of HIT, initiated by heparin and PF4 complexes. Biologic and pathogenic roles for PF4 have been suggested in many immune and developmental processes, such as atherosclerosis, vessel injury, angiogenesis, and megakaryopoiesis $(29,34,62,63)$. These processes are largely innate immune dependent, and PF4 exerts a proinflammatory effect. However, in the $\mathrm{CD}^{+}$-driven transplant disease model, platelets have a protective effect by limiting Th17 differentiation and maintaining Th homeostasis. In addition to anticoagulant effects, heparin has poorly understood inflammatory effects. Some studies have indicated that heparin is antiinflammatory; however, heparin treatment for psoriasis increased disease severity (64). PF4 and heparin complexes are the immunogenic initiator of HIT, but there have been no studies indicating a Th17 association with HIT, perhaps because HIT disease course and associated thrombocytopenia are very acute, and $\mathrm{T}$ cell involvement at the time of disease onset itself may be limited.

Acute and chronically thrombocytopenic mice have been used to suggest roles for platelets in inflammatory disease. In light of our findings that platelets help shape Th cell responses, it may be important to consider background immune alterations in plateletdeficient models when interpreting data using these mice. It is likely that acute platelet depletion will have little effect on Th cell development and responses because the decline in plasma PF4 is acute and transient. However, when using chronically plateletdeficient mice, background $\mathrm{T}$ cell alterations may lead to outcomes independent of platelet hemostatic functions. PF4 expression also is induced upon $\mathrm{T}$ cell activation. Others have identified PF4 expression in hematopoietic stem cells and monocytes (57, 65 ), indicating that PF4 may not be as platelet specific as previously thought. T cell PF4 production is not apparent until after cell stimulation, but our data clearly demonstrate that $\mathrm{T}$ cells express PF4 after activation and that stimulated T cell-derived PF4 has a major role in $\mathrm{T}$ cell differentiation. This unexpected expression of PF4 is unlikely to have an effect on mice genetically modified using Pf4-Cre to achieve platelet-specific knockout in most studies, but when considering platelet involvement in models of chronic inflammation, it may present a confounding variable.

Th17 cells initially were associated with autoimmune disease (40), but the physiologic function of Th17 cells is thought to be primarily in antimicrobial responses to bacteria and fungi by IL-17-induced neutrophil activation and migration, and stimulation of endothelial cells $(42,43)$. PF4 and Th17 differentiation also may be important in thrombosis, as IL-17 also increases platelet activation and aggregation $(66,67)$. Low concentrations of plasma $\mathrm{PF} 4$, therefore, may increase IL-17 in an attempt to compensate for fewer platelets by increasing platelet and endothelial activation. It is also unclear where PF4 and $\mathrm{CD}^{+}{ }^{+} \mathrm{T}$ cell interactions take place. Th17 cells are abundant at a steady state in lymphoid tissues of the gastrointestinal (GI) tract $(68,69)$. Platelets acquire serotonin in the GI tract, indicating potential "cargo exchange" in this tissue bed that may also affect Th17 differentiation.

Platelets are now recognized as part of the immune system. It is evident that platelets have major roles in immune development and responses in both health and disease states $(8,70)$. Our study identifies a previously unknown immune role for platelets in Th differentiation. As we continue to gain a deeper appreciation for platelets as part of the immune system, other disease-relevant roles for platelets in adaptive immune responses are likely to be discovered.

\section{Methods}

Cell isolation. Cells were isolated in PBS with 1\% penicillin and streptomycin and 2\% FBS. Cell counts were made using a VetScan HM5 (Abaxis) hemocytometer prior to staining. T cells were isolated using EasySep Mouse Cell Enrichment kits (Stem Cell Technology).

Cells were stained using antibodies and buffers from the mouse Th17 4-Color Flow Cytometry Kit (R\&D Systems) using the corresponding intracellular staining protocol provided by the company. ELISA kits were also purchased from R\&D Systems.

Recombinant mouse PF4 was purchased from Prospec, human PF4 from R\&D Systems, and recombinant TGF- $\beta$ from BioLegend. Anti-TGF- $\beta$ antibody was purchased from Abcam.

Cardiac transplants were performed as described (71). Briefly, the heart of a BM12 mouse is removed and sutured into the abdominal aorta and inferior vena cava of recipient mouse on a B6 background. The heart is checked daily for a beat by abdominal palpation.

$P f 4^{-/-}$mice were generated in the laboratory of Mortimer Poncz (Children's Hospital of Philadelphia, Philadelphia, Pennsylvania, USA), and Pf4 mice were provided by Genentech, each on a B6 background. WT B6 mice, Pf4-Cre, and Rosa26 EYFP reporter mice were each purchased from the Jackson Laboratory.

All images of heart grafts were taken with a $\times 20$ objective lens.

Malaria infections were performed using the nonlethal strain Plasmodium yoelii XNL. Mice were infected with $1 \times 10^{6}$ infected red blood cells delivered via intraperitoneal injection.

Real-time quantitative PCR. Total RNA was extracted from mouse hearts, primary $\mathrm{T}$ lymphocytes, or Jurkat cells using RNAasy Kits from QIAGEN, and mRNA was converted to cDNA using a High Capacity RNA-to-cDNA kit from Applied Biosystems according to the manufacturer's instructions. cDNA was subjected to qRT-PCR using the SYBR Green Supermix (BioRad). Predesigned primers were purchased from QIAGEN. At least three internal controls (actin, ribosomal protein L4, and TATA box binding protein) were used for quantification. For each experiment, expression of a given gene was compared with each internal control (IC). For example, to compare the expression of gene $\mathrm{X}$ in $\mathrm{WT}$ and $\mathrm{KO}$, we determined a ratio for $\mathrm{X} / \mathrm{IC} 1, \mathrm{X} / \mathrm{IC} 2$, or $\mathrm{X} / \mathrm{IC} 3$ for both WT and $\mathrm{KO}$. Then the KO/WT ratio was calculated as (KO/IC1)/(WT/IC1), (KO/IC2)/(WT/IC2), or (KO/IC3)/(WT/ IC3), and the final $\mathrm{KO} / \mathrm{WT}$ ratio is the average of the three.

TGF- $\beta$ signaling. Jurkat cells (clone E6-1) were purchased from ATCC and kept in RPMI-1640 plus 10\% FBS (Invitrogen). Jurkat cells were resuspended in serum-free media and then incubated with $5 \mathrm{ng} / \mathrm{ml}$ of human recombinant TGF- $\beta 1$ (BioLegend). To examine PF4 effects, $1 \mu \mathrm{g} / \mathrm{ml}$ human PF4 (Haematologic Technologies Inc.) was incubated with TGF- $\beta 1$ for 30 minutes, and then the mixture was added to the media. Naive 
mouse $\mathrm{CD} 4^{+} \mathrm{T}$ cells were isolated as described above and incubated with mouse TGF- $\beta 1$ and PF4, as in the Jurkat studies. Cell lysates were analyzed by SDS-PAGE and immunoblotted using rabbit monoclonal antibody against phospo-SMAD2/3 (Cell Signaling Technology). Polyclonal antibody against Smad2/3 (Cell Signaling Technology) was used on lysates as a loading control. Bound primary antibodies were detected by horseradish peroxidase-conjugated anti-rabbit IgG (GE Healthcare Life Sciences).

Statistics. Unless otherwise noted, statistics was performed by 2 -tailed Students $t$ test, and error bars represent SD. Graft survival significance was determined by a log-rank test. $P<0.05$ was considered significant.

Study approval. All animal studies were approved by the University of Rochester School of Medicine and Dentistry Institutional Animal Care and Use Committee.

\section{Acknowledgments}

Funding to Craig N. Morrell to support this work was provided by the American Heart Association (13EIA14250023) and the NIH/ NHLBI (R01 HL093179).

Received for publication June 27, 2013, and accepted in revised form November 7, 2013.

Address correspondence to: Craig N. Morrell, University of Rochester School of Medicine and Dentistry, 601 Elmwood Ave., ACVRI - 211 Bailey Road, Rochester, New York 14642, USA. Phone: 585.276.9921; Fax: 585.276.1947; E-mail: Craig_Morrell@ URMC.Rochester.edu.
1. Boilard E, et al. Platelets amplify inflammation in arthritis via collagen-dependent microparticle production. Science. 2010;327(5965):580-583.

2. Gawaz M, Favaloro EJ. Platelets, inflammation and cardiovascular diseases. New concepts and therapeutic implications. Semin Thromb Hemost. 2010;36(2):129-130.

3. Gawaz M, Langer H, May AE. Platelets in inflammation and atherogenesis. J Clin Invest. 2005 ; 115(12):3378-3384.

4. Smyth SS, et al. Platelet functions beyond hemostasis. J Thromb Haemost. 2009;7(11):1759-1766.

5. Ombrello C, Block RC, Morrell CN. Our expanding view of platelet functions and its clinical implications. J Cardiovasc Transl Res. 2010;3(5):538-546.

6. Baldwin WM, Baldwin WM 3rd, Kuo HH, Morrell $\mathrm{CN}$. Platelets: versatile modifiers of innate and adaptive immune responses to transplants. Curr Opin Organ Transplant. 2010;16(1):41-46.

7. Morrell CN, et al. In vivo platelet-endothelial cell interactions in response to major histocompatibility complex alloantibody. Circ Res. 2008;102(7):777-785.

8. Shi G, Morrell CN. Platelets as initiators and mediators of inflammation at the vessel wall. Thromb Res. 2010;127(5):387-390.

9. Weyrich A, Cipollone F, Mezzetti A, Zimmerman G. Platelets in atherothrombosis: new and evolving roles. Curr Pharm Des. 2007;13(16):1685-1691.

10. Massberg S, et al. Platelets secrete stromal cellderived factor 1alpha and recruit bone marrowderived progenitor cells to arterial thrombi in vivo. J Exp Med. 2006;203(5):1221-1233.

11. Gawaz M. Role of platelets in coronary thrombosis and reperfusion of ischemic myocardium. Cardiovasc Res. 2004;61(3):498-511.

12. Langer $\mathrm{H}$, et al. Adherent platelets recruit and induce differentiation of murine embryonic endothelial progenitor cells to mature endothelial cells in vitro. Circ Res. 2006;98(2):e2-e10.

13. Huo Y, et al. Circulating activated platelets exacerbate atherosclerosis in mice deficient in apolipoprotein E. Nat Med. 2003;9(1):61-67.

14. von Hundelshausen P, et al. RANTES deposition by platelets triggers monocyte arrest on inflamed and atherosclerotic endothelium. Circulation. 2001;103(13):1772-1777.

15. Bustos M, Saadi S, Platt JL. Platelet-mediated activation of endothelial cells: implications for the pathogenesis of transplant rejection. Transplantation. 2001;72(3):509-515.

16. Kirk AD, Morrell CN, Baldwin WM. Platelets influence vascularized organ transplants from start to finish. Am J Transplant. 2009;9(1):14-22.

17. Porter KA. Morphological aspects of renal homograft rejection. Br Med Bull. 1965;21:171-175.

18. Fenech A, Nicholls A, Smith FW. Indium (111In)labelled platelets in the diagnosis of renal transplant rejection: preliminary findings. $\mathrm{Br} J$ Radiol. 1981;54(640):325-327.

19. Oluwole S, et al. Use of indium-111-labeled cells in measurement of cellular dynamics of experimental cardiac allograft rejection. Transplantation. 1981;31(1):51-55

20. Xu H, Zhang X, Mannon RB, Kirk AD. Plateletderived or soluble CD154 induces vascularized allograft rejection independent of cell-bound CD154. J Clin Invest. 2006;116(3):769-774.

21. Swaim AF, Field DJ, Fox-Talbot K, Baldwin WM Baldwin WM 3rd, Morrell CN. Platelets contribute to allograft rejection through glutamate receptor signaling. J Immunol. 2010;185(11):6999-7006.

22. Fischereder M. Chemokines and chemokine receptors in renal transplantation--from bench to bedside. Acta Physiol Hung. 2007;94(1-2):67-81.

23. Schnickel GT, Hsieh GR, Garcia C, Shefizadeh A, Fishbein MC, Ardehali A. Role of CXCR3 and CCR5 in allograft rejection. Transplant Proc. 2006; 38(10):3221-3224.

24. Hoffmann U, et al. Expression of the chemokine receptor CXCR3 in human renal allografts-a prospective study. Nephrol Dial Transplant. 2006;21(5):1373-1381.

25. Baltus T, von Hundelshausen P, Mause SF, Buhre W, Rossaint R, Weber C. Differential and additive effects of platelet-derived chemokines on monocyte arrest on inflamed endothelium under flow conditions. J Leukoc Biol. 2005;78(2):435-441.

26. von Hundelshausen P, Petersen F, Brandt E. Platelet-derived chemokines in vascular biology. Thromb Haemost. 2007;97(5):704-713.

27. Luther SA, Cyster JG. Chemokines as regulators of T cell differentiation. Nat Immunol. 2001;2(2):102-107.

28. Sachais BS, Higazi AA, Cines DB, Poncz M, Kowalska MA. Interactions of platelet factor 4 with the vessel wall. Semin Thromb Hemost. 2004;30(3):351-358.

29. Lambert MP, Rauova L, Bailey M, Sola-Visner MC, Kowalska MA, Poncz M. Platelet factor 4 is a negative autocrine in vivo regulator of megakaryopoiesis: clinical and therapeutic implications. Blood. 2007;110(4):1153-1160

30. Amiral J, Marfaing-Koka A, Poncz M, Meyer D. The biological basis of immune heparin-induced thrombocytopenia. Platelets. 1998;9(2):77-91.

31. Arepally GM, et al. Characterization of a murine monoclonal antibody that mimics heparininduced thrombocytopenia antibodies. Blood. 2000; 95(5):1533-1540.

32. Ziporen L, et al. Defining an antigenic epitope on platelet factor 4 associated with heparin-induced thrombocytopenia. Blood. 1998;92(9):3250-3259.

33. Eslin DE, et al. Transgenic mice studies demonstrate a role for platelet factor 4 in thrombosis: dissociation between anticoagulant and antithrombotic effect of heparin. Blood. 2004;104(10):3173-3180.

34. Koenen RR, et al. Disrupting functional interactions between platelet chemokines inhibits atherosclerosis in hyperlipidemic mice. Nat Med. 2009;15(1):97-103.

35. Sachais BS, Turrentine T, Dawicki McKenna JM, Rux AH, Rader D, Kowalska MA. Elimination of platelet factor 4 (PF4) from platelets reduces ath- erosclerosis in $\mathrm{C} 57 \mathrm{Bl} / 6$ and apoE $\mathrm{E}^{-/-}$mice. Thromb Haemost. 2007;98(5):1108-1113.

36. Aziz KA, Cawley JC, Zuzel M. Platelets prime PMN via released PF4: mechanism of priming and synergy with GM-CSF. BrJ Haematol. 1995;91(4):846-853.

37. Engstad CS, Lia K, Rekdal O, Olsen JO, Osterud B. A novel biological effect of platelet factor 4 (PF4): enhancement of LPS-induced tissue factor activity in monocytes. J Leukoc Biol. 1995;58(5):575-581.

38. Srivastava K, et al. Platelet factor 4 mediates inflammation in experimental cerebral malaria. Cell Host Microbe. 2008;4(2):179-187.

39. Liu CY, Battaglia M, Lee SH, Sun QH, Aster RH, Visentin GP. Platelet factor 4 differentially modulates CD4+CD25+ (regulatory) versus CD4+CD25- (nonregulatory) T cells. JImmunol. 2005;174(5):2680-2686.

40. Afzali B, Lombardi G, Lechler RI, Lord GM. The role of T helper 17 (Th17) and regulatory T cells (Treg) in human organ transplantation and autoimmune disease. Clin Exp Immunol. 2007;148(1):32-46.

41. Gocke AR, et al. T-bet regulates the fate of Th1 and Th17 lymphocytes in autoimmunity. J Immunol. 2007;178(3):1341-1348.

42. Pappu R, Ramirez-Carrozzi V, Ota N, Ouyang W, $\mathrm{Hu}$ Y. The IL-17 family cytokines in immunity and disease. J Clin Immunol. 2010;30(2):185-195.

43. Bettelli E, Korn T, Oukka M, Kuchroo VK. Induction and effector functions of $\mathrm{T}(\mathrm{H}) 17$ cells. Nature. 2008;453(7198):1051-1057.

44. Loverre A, et al. T helper 1, 2 and 17 cell subsets in renal transplant patients with delayed graft function. Transpl Int. 2011;24(3):233-242.

45. Shilling RA, Wilkes DS. Role of Th17 cells and IL-17 in lung transplant rejection. Semin Immunopathol. 2011;33(2):129-134.

46. Yuan X, et al. A novel role of CD4 Th17 cells in mediating cardiac allograft rejection and vasculopathy. J Exp Med. 2008;205(13):3133-3144.

47. Shi G, et al. Platelet factor 4 mediates vascular smooth muscle cell injury responses. Blood. 2013; 121(21):4417-4427

48. Nagano H, Mitchell RN, Taylor MK, Hasegawa S, Tilney NL, Libby P. Interferon-gamma deficiency prevents coronary arteriosclerosis but not myocardial rejection in transplanted mouse hearts. J Clin Invest. 1997;100(3):550-557.

49. Hasegawa T, Visovatti SH, Hyman MC, Hayasaki T, Pinsky DJ. Heterotopic vascularized murine cardiac transplantation to study graft arteriopathy. Nat Protoc. 2007;2(3):471-480.

50. Gramzinski RA, Doolan DL, Sedegah M, Davis HL, Krieg AM, Hoffman SL. Interleukin-12- and $\gamma$ interferon-dependent protection against malaria conferred by CpG oligodeoxynucleotide in mice. Infect Immun. 2001;69(3):1643-1649.

51. Amante FH, Good MF. Prolonged Th1-like response generated by a Plasmodium yoelii-specific $\mathrm{T}$ cell clone allows complete clearance of infection in reconstituted mice. Parasite Immunol. 1997;19(3):111-126.

52. Ishida H, et al. Development of experimental cere- 
bral malaria is independent of IL-23 and IL-17. Biochem Biophys Res Commun. 2010;402(4):790-795.

53. Mucida D, et al. Reciprocal TH17 and regulatory $T$ cell differentiation mediated by retinoic acid. Science. 2007;317(5835):256-260.

54. Whitson RH, Whitson RH Jr, Wong WL, Itakura K. Platelet factor 4 selectively inhibits binding of TGF- $\beta 1$ to the type I TGF- $\beta 1$ receptor. J Cell Biochem. 1991;47(1):31-42.

55. Gurney AL, Carver-Moore K, de Sauvage FJ, Moore MW. Thrombocytopenia in c-mpl-deficient mice. Science. 1994;265(5177):1445-1447.

56. Maier M, et al. Platelet factor 4 is highly upregulated in dendritic cells after severe trauma. Mol Med. 2009;15(11-12):384-391.

57. Schaffner A, Rhyn P, Schoedon G, Schaer DJ. Regulated expression of platelet factor 4 in human monocytes - role of PARs as a quantitatively important monocyte activation pathway. J Lenkoc Biol. 2005;78(1):202-209.

58. Lasagni L, et al. An alternatively spliced variant of CXCR3 mediates the inhibition of endothelial cell growth induced by IP-10, Mig, and I-TAC, and acts as functional receptor for platelet factor 4. J Exp
Med. 2003;197(11):1537-1549.

59. Mueller A, et al. CXCL4-induced migration of activated $\mathrm{T}$ lymphocytes is mediated by the chemokine receptor CXCR3. J Lenkoc Biol. 2008;83(4):875-882.

60. Rocha AM, et al. The levels of IL-17A and of the cytokines involved in Th17 cell commitment are increased in patients with chronic immune thrombocytopenia. Haematologica. 2011;96(10):1560-1564.

61. John ML, Scharrer I. Autoimmune disorders in patients with idiopathic thrombotic thrombocytopenic purpura. Hamostaseologie. 2012; 32(suppl 1):S86-S89.

62. Sachais BS, et al. Platelet factor 4 binds to lowdensity lipoprotein receptors and disrupts the endocytic machinery, resulting in retention of lowdensity lipoprotein on the cell surface. Blood. 2002; 99(10):3613-3622.

63. Aidoudi S, Bikfalvi A. Interaction of PF4 (CXCL4) with the vasculature: a role in atherosclerosis and angiogenesis. Thromb Haemost. 2010;104(5):941-948.

64. Chacko MK, Mathew T, Sugathan P, Nair LV. Heparin in psoriasis. Indian J Dermatol Venereol Leprol. 1998;64(6):273-274.

65. Calaminus SD, et al. Lineage tracing of Pf4-Cre marks hematopoietic stem cells and their progeny. PLoS One. 2012;7(12):e51361.

66. Maione F, Cicala C, Liverani E, Mascolo N, Perretti M, D'Acquisto F. IL-17A increases ADP-induced platelet aggregation. Biochem Biophys Res Commun. 2011;408(4):658-662.

67. Zhang S, et al. IL-17A facilitates platelet function through the ERK2 signaling pathway in patients with acute coronary syndrome. PLoS One. 2012; 7(7):e40641.

68. Ivanov II, et al. Specific microbiota direct the differentiation of IL-17-producing T-helper cells in the mucosa of the small intestine. Cell Host Microbe. 2008;4(4):337-349.

69. Ivanov II, et al. Induction of intestinal Th17 cells by segmented filamentous bacteria. Cell. 2009; 139(3):485-498.

70. Morrell CN, Sun H, Swaim AM, Baldwin WM. Platelets an inflammatory force in transplantation. Am J Transplant. 2007;7(11):2447-2454.

71. Wasowska BA, Qian Z, Behrens E, Cangello D, Sanfilippo F, Baldwin WM. Inhibition of acute cardiac allograft rejection in immunoglobulin-deficient mice. Transplant Proc. 1999;31(1-2):136. 